\title{
Enzyme-linked immunosorbent assay (ELISA) for the detection of hepatitis Be antigen and antibody: report of a field trial
}

\author{
E MARGARET SUPRAN, ${ }^{*}$ ELIZABETH H BOXALL $\ddagger$ J CRASKE,§ RJC HART \#ELISE M \\ VANDERVELDE, $\dagger$ PS GARDNER*
}

\begin{abstract}
From the ${ }^{*}$ Division of Microbiological Reagents and Quality Control, the $†$ Virus Reference Laboratory, Central Public Health Laboratory, Colindale Avenue, London NW9 5HT, the $\ddagger$ Regional Virus Laboratory, East Birmingham Hospital, the §Public Health Laboratory, Manchester, and the $\|$ Public Health Laboratory, Exeter
\end{abstract}

SUMMARY A field trial of an enzyme-linked immunosorbent assay (ELISA) for the detection of the hepatitis Be markers is reported. It is simple to perform, is designed to be read by eye and does not require any expensive apparatus. When compared with a commercially available RIA kit for the detection of the same markers, ELISA was shown to be as sensitive as RIA for the detection of anti-HBe but slightly less sensitive for the detection of $\mathrm{HBeAg}$. However if all specimens negative for both $\mathrm{HBeAg}$ and anti-HBe by ELISA are considered to be potentially infectious, the ELISA should prove to be as useful as RIA for determining the " $\mathrm{e}$ " status of HBsAg-positive patients and, therefore, provide a reliable indication of the risk of secondary spread of hepatitis B infection to contacts by needle stick accident, close personal contact or perinatal transmission.

The description of hepatitis $\mathrm{Be}$ antigen $(\mathrm{HBeAg})$ and its antibody (anti-HBe) by Magnius in $1972^{1}$ has helped to elucidate the epidemiology of hepatitis $B$ infection, particularly with reference to the risk of secondary infection through contact with hepatitis B carriers. ${ }^{2}$ The risk of persistent hepatitis $B$ infection in children borne to women who contract acute hepatitis B in the last trimester of pregnancy, or who are $\mathrm{HBeAg}$-positive carriers is $90 \%{ }^{3}$ whereas, women who are anti-HBe carriers have a small chance (about $10 \%$ ) of transmitting acute hepatitis $B$ to their children. The latter almost invariably recover with a complete resolution of their infection. It was also shown by Grady, ${ }^{4}$ who re-evaluated the results of a trial of hepatitis $B$ immunoglobulin (HBIg) in inoculation accidents, that the risk of transmission of infection was $19 \%$ when the source of infection was $\mathrm{HBeAg}$-positive compared with $1.9 \%$ in $\mathrm{HBeAg}$-negative patients.

There is therefore an urgent need for a sensitive immune assay for hepatitis B " $e$ " markers for use in the clinical virology laboratory. One of the difficulties has been that of purifying $\mathrm{HBeAg}$ from human

Accepted for publication 22 December 1982 plasma and raising an antiserum in laboratory animals. Consequently radioimmunoassay (RIA) and enzyme-linked immunosorbent assays (ELISA) currently available make use of anti-HBe conjugates and $\mathrm{HBeAg}$ prepared from human serum. Commercially produced assays are very expensive and require expensive counters and spectrophotometers for their performance. Smith and Tedder ${ }^{5}$ described an ELISA for the detection of $\mathrm{HBeAg}$ and anti$\mathrm{HBe}$ which was simple to perform, had a sensitivity approaching that of RIA, and yet was designed to be read by eye. This test did not necessitate the use of radioactive substances or sophisticated equipment and the reagents used had a long shelf life. It seemed ideal for use in the Public Health Laboratory Service (PHLS), as the assay tested for both HBeAg and anti-HBe at the same time and incorporated a confirmatory test for $\mathrm{HBeAg}$. Therefore with sera supplied by the North London Blood Transfusion Centre, Edgware, a field trial was started.

DESIGN OF THE TRIAL

The Division of Microbiological Reagents and Quality Control (DMRQC) and four collaborating laboratories took part, one of which had no previous 
ELISA experience. To familiarise themselves with the test before the commencement of the trial, the laboratories were issued with a small panel of specimens and reagents. When preliminary tests were satisfactorily completed, each collaborating laboratory was asked to select $40-50 \mathrm{HBsAg}$ positive serum specimens from their own clinical specimen banks and test them for the " $e$ " markers using the ELISA reagents supplied by DMRQC. These specimens, which included acute and convalescent sera from patients with hepatitis $B$, as well as specimens from HBsAg carriers, were then sent to DMRQC for testing again using the same batch of ELISA reagents. The sera were then forwarded to the Virus Reference Laboratory, Colindale to be tested by RIA using Abbott-HBe kits (Abbott Laboratories, $\mathrm{N}$ Chicago, Illinois). Thus a comparison was made of the results obtained by workers in the field laboratories and at DMRQC, and the sensitivities of ELISA and RIA were directly compared.

\section{Material and methods}

\section{THE ELISA SOLID PHASE}

The wells of Nunc immunoplates I (polystyrene micro ELISA plates supplied by Gibco Europe Ltd, Uxbridge, Middlesex) were coated with $0.1 \mathrm{ml}$ volumes of a 1/100 dilution of the IgG fraction of a high titre anti-HBe-positive serum. The IgG was obtained by double precipitation with $40 \%$ saturated ammonium sulphate solution, the second precipitate being dissolved to the original volume in $0.02 \mathrm{M}$ Tris- $\mathrm{HCl}$ buffer $\mathrm{pH} 7.2$ plus $0.1 \%$ sodium azide. The coating buffer was the same Tris buffer and coating was accomplished by leaving the plates at room temperature for $72 \mathrm{~h}$. The plates were then washed three times with coating buffer before the wells were "quenched" by filling completely with Tris buffer containing $0.5 \%$ bovine serum albumin and leaving for at least one hour at room temperature. Before being sealed for storage at $4^{\circ} \mathrm{C}$, some quenching buffer was aspirated leaving approximately $0.2 \mathrm{ml}$ volume in each well. Plates could not be posted in this condition however as it proved impossible to make them leakproof. Therefore just before dispatch to the collaborating laboratories, the remaining quenching buffer was aspirated from the wells and the plates resealed whilst the wells were still moist. A supply of fresh quenching buffer (storage buffer) was posted with each plate with instructions to the recipient to add $0.2 \mathrm{ml}$ to each well immediately on arrival and to reseal the plate for storage at $4^{\circ} \mathrm{C}$ until ready for use. Tests conducted by DMRQC showed this to be the simplest way of preparing plates for posting, the plates remaining satisfactory for use even if they took several days to reach their destination.

\section{CONJUGATE}

The sodium periodate method of Nakane and Kawaoi $^{6}$ was employed in the preparation of the horseradish peroxidase conjugate. The freshly prepared conjugate was fractionated immediately through Sepharose CL-6B (Pharmacia Fine Chemicals, Uppsala, Sweden) in order to separate any aggregated conjugate or unconjugated free enzyme. The IgG for conjugation was obtained by ionexchange chromatography using DE52 (Whatman Ltd) equilibrated with $0.02 \mathrm{M}$ phosphate buffer $\mathrm{pH}$ 8.0 from a human serum with a high titre of anti$\mathrm{HBe}$. In order to avoid false-positive reactions due to any rheumatoid factor present in the specimens under test, heat aggregated normal IgG $(0.5 \mathrm{mg} / \mathrm{ml})$ was added to the conjugate buffer.

\section{SUBSTRATE}

As the test had been designed to be read by eye, ABTS, 2,2'-azino-di-(3-ethyl-benzthiazoline sulphonic acid), rather than $o$-phenylenediamine, had been chosen as the chromatogen because the reaction, colourless to blue-green, produced with ABTS made weakly positive reactions easier to see.

\section{PRELIMINARY TESTS}

Initially the collaborating laboratories were given a panel of seven specimens (I-VII) plus one specimen containing the cut off control (reference colour standard), and all reagents necessary for the test except the washing buffer (PBS $+0.05 \%$ Tween 20 ) and hydrogen peroxide which they were asked to provide themselves. One plate was supplied with the wells in the top half of the plate coated with anti$\mathrm{HBe}$. This enabled workers to perform the initial tests on two separate occasions, using the top three rows of the plate on the first occasion, and the next three rows on the second (Fig. 1). Coated wells Specimens

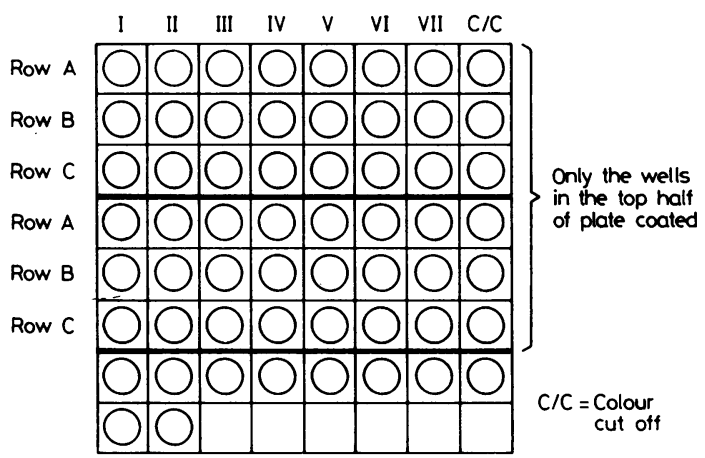

Fig. 1 Lay-out for the preliminary tests. 
which were not used on the first occasion were kept sealed during the performance of the test. Specimens V, VI, VII ( $\mathrm{HBeAg}$ positive, anti-HBe positive, $\mathrm{HBeAg}$ and anti-HBe-negative), and the cutoff control constituted control sera which were retained for inclusion in later tests.

Each specimen under test requires a column of three wells (Fig. 1). The first well (row A) incorporates a neutralisation test with a standard $\mathrm{HBeAg}$ reactant to detect the presence of anti-HBe in the specimen; the second well (row B) detects the presence of $\mathrm{HBeAg}$; and the third well (row $\mathrm{C}$ ) confirms the specificity of any $\mathrm{HBeAg}$ present by the neutralisation of a standard anti-HBe reactant added to that well. Basically, $50 \mu \mathrm{l}$ volumes of the specimen are added to each of the three wells and mixed with $50 \mu \mathrm{l}$ standard $\mathrm{HBeAg}$ reactant in row $\mathrm{A}, 50 \mu \mathrm{l}$ normal human serum (NHS) in row B, and $50 \mu \mathrm{l}$ standard anti-HBe reactant in row $\mathrm{C}$. The cut-off is a colour standard and consists of a dilution of a reference $\mathrm{HBeAg}$-positive serum such that the colour release in the wells is just within the limits of visual discrimination.

Because of the number of steps involved it was felt necessary to enumerate carefully each stage. These are included in Appendix I.

\section{Results}

One hundred and seventy-one specimens were received from the collaborating laboratories. By RIA, 71 specimens $(41.5 \%)$ were $\mathrm{HBeAg}$-positive: 87 specimens $(50.8 \%)$ were positive for anti-HBe: and 13 specimens $(7.6 \%)$ were apparently negative for both $\mathrm{HBeAg}$ and anti-HBe. The corresponding ELISA results obtained by the collaborating laboratories and DMRQC are given in Tables 1, 2, and 3.

Table 1 Results obtained by ELISA in the 71 specimens positive by RIA for $\mathrm{HBeAg}$

\begin{tabular}{|c|c|c|}
\hline \multirow[t]{2}{*}{ No } & \multicolumn{2}{|l|}{ ELISA } \\
\hline & $\begin{array}{l}\text { Results reported by the } \\
\text { collaborating laboratory }\end{array}$ & $D M R Q C$ result \\
\hline $\begin{array}{r}57 \\
1 \\
7\end{array}$ & $\begin{array}{l}\mathrm{e}^{+} \\
\mathrm{e}^{+} \\
\text {Neither }\end{array}$ & $\begin{array}{l}\mathrm{e}^{+} \\
\text {Neither } \\
{ }^{*} \text { Neither (but a } \\
\text { suggestion of weak } \mathrm{e}^{+} \text {) }\end{array}$ \\
\hline $\begin{array}{l}5 \\
1 \dagger\end{array}$ & $\begin{array}{l}\text { Neither } \\
\mathrm{e}^{+}\end{array}$ & $\begin{array}{l}\text { Neither } \\
\text { Neither }\end{array}$ \\
\hline
\end{tabular}

*Some colour development, but below the cut-off level, in the wells of row $A$ and $B$.

†Probably an erroneous result.

$\mathrm{e}^{+}=\mathrm{HBeAg}$ positive

anti-e $=$ anti-HBe positive

Neither = neither $\mathrm{HBeAg}$ nor anti-HBe detectable.
Table 2 Results obtained by ELISA in the 87 specimens positive by $\mathrm{RIA}$ for anti-HBe

\begin{tabular}{rll}
\hline No & ELISA \\
\cline { 2 - 3 } & $\begin{array}{l}\text { Result reported by the } \\
\text { collaborating laboratory }\end{array}$ & DMRQC result \\
\hline 84 & Anti-e & Anti-e \\
2 & Neither & Anti-e \\
1 & Anti-e & Neither \\
\hline
\end{tabular}

Table 3 Results obtained by ELISA in the 13 specimens negative by $\mathrm{RIA}$ for both $\mathrm{HBeAg}$ and anti-HBe

\begin{tabular}{lll}
\hline No & ELISA \\
\cline { 2 - 3 } & $\begin{array}{l}\text { Result reported by the } \\
\text { collaborating laboratory }\end{array}$ & DMRQC result \\
\hline 9 & Neither & Neither \\
2 & Neither & Anti-e \\
1 & Anti-e & Neither \\
1 & Anti-e & Anti-e \\
\hline
\end{tabular}

There were 30 specimens which gave rather indeterminate results in that they were negative for $\mathrm{HBeAg}$ and anti-HBe either by RIA or ELISA (see Tables 1 and 2, omitting the top line of each Table and Table 3). Nine of these 30 specimens (30\%) gave completely negative results by RIA and by ELISA whether carried out in the collaborating laboratory or DMRQC. Fourteen $(47 \%)$ were HBeAg-positive by RIA only (Table 1 ) and seven $(23 \%)$ were anti-HBe-positive only by ELISA (Tables 2 and 3 ). If the ELISA results are considered separately, 29 specimens were reported as negative for the " $e$ " markers by the collaborating laboratory and/or DMRQC. Of these ELISA negatives, $14(48 \%)$ were shown subsequently to be positive for $\mathrm{HBeAg}$ by RIA.

\section{Discussion}

There was good correlation between ELISA and RIA in the detection of anti-HBe. Eighty-seven specimens in this series were positive for anti-HBe by RIA (Table 2) and of these $84(97 \%)$ were detected by ELISA in both the collaborating laboratories and at $\mathrm{DMRQC}$, and the remaining three either by the collaborating laboratory or DMRQC. There were 13 specimens negative for both $\mathrm{HBeAg}$ and anti-HBe by RIA. Of these, one was positive for anti-HBe when tested by ELISA in both the collaborating laboratory and DMRQC. Three others were found to be anti-HBe-positive by ELISA by either the collaborating laboratory or 
DMRQC. Thus, four of the specimens negative by RIA possessed anti-HBe detectable by ELISA. Therefore, overall, the sensitivity of the two assays for anti-HBe appears to be broadly similar. No specimen negative by RIA was shown to be positive for $\mathrm{HBeAg}$ by ELISA.

It is clear (Table 1) that RIA is more sensitive for the detection of $\mathrm{HBeAg}$. Of the specimens positive for $\mathrm{HBeAg}$ by RIA, only $57 / 71(80 \%)$ were detected by ELISA by both the collaborating laboratory and DMRQC with one additional antigen detected by ELISA by the collaborating laboratory only. However, the presence of $\mathrm{HBeAg}$ was suggested in seven of the antigen-positive sera undetected by ELISA by the development of traces of colour in the wells of rows A and B. Among the specimens positive for $\mathrm{HBeAg}$ by RIA, the average positive:negative ( $\mathrm{P}: \mathrm{N})$ count ratio was 13.5 for those specimens positive by both RIA and ELISA, whereas the average $P: N$ ratio of the specimens positive by RIA only was $7 \cdot 15$. The difference between the two assays arises from the increased sensitivity of RIA for lower levels of antigen. This is in agreement with the findings of Smith and Tedder ${ }^{5}$ who showed that it was the lower sensitivity of the ELISA for $\mathrm{HBeAg}$ that resulted in the seemingly paradoxical small increase in sensitivity of ELISA for the detection of anti-HBe by neutralisation.

One specimen (Table $1, \dagger$ ) reported by a collaborating laboratory as positive for anti-HBe by ELISA was subsequently shown to contain $\mathrm{HBeAg}$ on testing by RIA. When tested by ELISA at DMRQC, it was negative for $\mathrm{HBeAg}$ and there was no trace of any anti-HBe activity neutralising the $\mathrm{HBeAg}$ reactant added to well A. This was the only discrepant result in the whole trial and was obtained by the laboratory with the least ELISA experience.

When patients are undergoing seroconversion from $\mathrm{HBeAg}$ to anti- $\mathrm{HBe}$ mixtures of antigen and antibody may occur and during this time serum may still be infectious enough to carry a significant risk of transmission of hepatitis B by parenteral inoculation. If the ELISA were made too sensitive for the detection of antibody such a specimen might be reported as positive for anti-HBe, the $\mathrm{HBeAg}$ remaining sub-detectable. To minimise the chances of obtaining such a falsely reassuring result, Smith and Tedder deliberately designed the assay (by adjusting the dose of antigen to be neutralised added to well $A$ ) to leave $5-10 \%$ of carriers unclassified. If all specimens negative for anti-HBe when tested by ELISA are treated as potentially $\mathrm{HBeAg}$-positive, then this ELISA should prove to be a useful guide to the risk of transmission of hepatitis B by parenteral inoculation, close personal contact, or perinatal transmission.

\section{Appendix I}

TECHNICAL INSTRUCTIONS SENT TO

PARTICIPANTS FOR THE PERFORMANCE OF THE

PRELIMINARY TESTS

1 Aspirate storage buffer from three rows of wells.

2 Add $100 \mu$ l volumes of the "cut-off" control $(\mathrm{C} / \mathrm{C})$ to the last triplicate of wells.

To the rest of the wells except the $\mathrm{C} / \mathrm{C}$ triplicate:

3 Add $50 \mu$ l volumes of NHS to row B wells.

4 Add $50 \mu$ l volumes of the standard anti-HBe reactant to row $\mathrm{C}$ wells.

5 Add $50 \mu \mathrm{l}$ volumes of specimens I to VII to their own triplicates A, B, and C.

6 Add $50 \mu \mathrm{l}$ volumes of the standard $\mathrm{HBeAg}$ o reactant to wells of row $A$.

To all wells:

7 Seal wells with a plate sealer or strips of masking tape.

8 Incubate overnight at room temperature.

9 Immediately before step 10 make up the conjugate:

Dilute conjugate $1 / 100$ in the conjugate buffer. Only the exact amount of conjugate required for the test should be made up $(25 \mu$ l conjugate in $2.5 \mathrm{ml}$ conjugate buffer).

10 Wash all wells five times with PBS-Tween. Aspirate.

11 Add $100 \mu$ l conjugate to each well.

12 Cover plate and incubate at room temperature $\vec{F}$ for 2-3 h (keep to the same time each time you $\frac{O}{3}$ perform the test).

13 During this period, weigh out $4 \mathrm{mg}$ ABTS (keep in dark after weighing). Dilute $5 \mathrm{ml}$ substrate buffer with $5 \mathrm{ml}$ distilled water (bring to ? ambient temp) and check $\mathrm{pH}$ is 4.0 to $4 \cdot 1$. If necessary, adjust $\mathrm{pH}$ with citric acid provided. The $\mathrm{pH}$ is critical, $\mathrm{pH} 3.9$ or 4.2 will result in poor colour development. Do not dissolve ABTS in substrate buffer yet.

14 Wash plate five times with PBS-Tween. Aspi- $\frac{7}{2}$ rate.

15 Add the $4 \mathrm{mg} \mathrm{ABTS}$ to the $10 \mathrm{ml}$ substrate buf- N fer together with $64 \mu 1 \mathrm{H}_{2} \mathrm{O}_{2}$ (20 vols strength). Mix.

16 Add $100 \mu$ l volumes of the substrate to the wells.

17 Incubate in the dark for $30 \mathrm{~min}$ at room temp-e erature.

18 Add $50 \mu \mathrm{l} 0.2 \%$ sodium fluoride solution to each well to stop the reaction.

19 Read colour pattern by eye. Many individuals are able to detect colour $\stackrel{\mathbb{\Omega}}{\varrho}$ below the level of the colour in the reference $\stackrel{\square}{\square}$ cut-off control wells. However wells should be 
scored as positive $\mathrm{HBeAg}$ only if the chromogen release is equal to or greater than that of the cut-off control. The test may be read spectrophotometrically at $650 \mathrm{~nm}$ if desired (Fig. 2).

\begin{tabular}{|c|c|c|c|c|}
\hline & $\begin{array}{c}\mathrm{HB}_{\text {eAg }} \mathrm{Ag} \\
\mathrm{ve}\end{array}$ & $\begin{array}{c}\text { Anti- } \mathrm{HB}_{\mathrm{e}} \\
\text {-ve }\end{array}$ & $\begin{array}{l}H_{e} A g \\
\text { anti-HBe } \\
\text {-ve }\end{array}$ & $\begin{array}{l}\text { Cut off } \\
\text { colour } \\
\text { control }\end{array}$ \\
\hline Row $A$ & 0 & 0 & 0 & $\theta$ \\
\hline Row $B$ & 0 & 0 & 0 & $\theta$ \\
\hline Row C & 0 & 0 & 0 & $\mathbb{8}$ \\
\hline
\end{tabular}

Fig. 2 Interpretation of colour patterns-occasionally a serum with very high levels of $\mathrm{HBeAg}$ will not be completely neutralised by the anti-HBe reactant added to well $\mathrm{C}$. Such a serum should be diluted $1 / 10$ and retested.

\section{References}

${ }^{1}$ Magnius LO, Espmark JA. New specificities in Australia antigen positive sera distinct from the LeBouvier determinants. $J$ Immunol 1972;109:1017.

${ }^{2}$ Alter HJ, Seeff LB, Kaplan PM, et al. Type B hepatitis: the infectivity of blood positive for e Antigen and DNA polymerase after accidental needlestick exposure. $N$ Engl $J$ Med 1976;295:909-13.

${ }^{3}$ Okada K, Kamiyama I, Inomata M, Imai M, Miyakawa Y, Mayumi M. e Antigen and anti-e in the serum of asymptomatic carrier mothers as indicators of positive and negative transmission of hepatitis B virus to their infants. $N$ Engl $J$ Med 1976;294:746-9.

4 Grady G, Szmuness W, Alter HJ, Maynard JE, eds. Viral hepatitis. Philadelphia: The Franklin Institute Press, 1981:202.

${ }^{5}$ Smith A, Tedder RS. Development of an enzyme-linked immunosorbent assay (ELISA) for hepatitis $\mathrm{Be}$ antigen and antibody. J Virol Methods 1981;3:1-11.

6 Nakane PK, Kawaoi A. Peroxidase-labelled antibody. A new method of conjugation. J Histochem Cytochem 1974;22:1084-91.

Requests for reprints to: Professor PS Gardner, Director, Central Public Health Laboratory, Division of Microbiological Reagents and Quality Control, 175 Colindale Avenue, London NW9 5HT, England. 